\title{
Homozygous deletion of the activin A receptor, type IB gene is associated with an aggressive cancer phenotype in pancreatic cancer
}

\author{
Yosuke Togashi ${ }^{1}$, Hiroki Sakamoto ${ }^{2}$, Hidetoshi Hayashi ${ }^{1}$, Masato Terashima ${ }^{1}$, Marco A de Velasco ${ }^{1}$, Yoshihiko Fujita',
} Yasuo Kodera', Kazuko Sakai ${ }^{1}$, Shuta Tomida ${ }^{1}$, Masayuki Kitano², Akihiko Ito ${ }^{3}$, Masatoshi Kudo ${ }^{2}$ and Kazuto Nishio ${ }^{{ }^{*}}$

\begin{abstract}
Background: Transforming growth factor, beta (TGFB) signal is considered to be a tumor suppressive pathway based on the frequent genomic deletion of the SMAD4 gene in pancreatic cancer (PC); however; the role of the activin signal, which also belongs to the TGFB superfamily, remains largely unclear.

Methods and results: We found a homozygous deletion of the activin A receptor, type IB (ACVRIB) gene in 2 out of 8 PC cell lines using array-comparative genomic hybridization, and the absence of ACVR1B mRNA and protein expression was confirmed in these 2 cell lines. Activin A stimulation inhibited cellular growth and increased the phosphorylation level of SMAD2 and the expression level of p21 $1^{\text {IP1 } 1 \text { WAF1 } 1}$ in the Sui66 cell line (wild-type ACVR1B and SMAD4 genes) but not in the Sui68 cell line (homozygous deletion of ACVR1B gene). Stable ACVR1B-knockdown using short hairpin RNA cancelled the effects of activin A on the cellular growth of the PC cell lines. In addition, ACVR1B-knockdown significantly enhanced the cellular growth and colony formation abilities, compared with controls. In a xenograft study, $A C V R 1 B$-knockdown resulted in a significantly elevated level of tumorigenesis and a larger tumor volume, compared with the control. Furthermore, in clinical samples, 6 of the 29 PC samples (20.7\%) carried a deletion of the ACVR1B gene, while 10 of the 29 samples (34.5\%) carried a deletion of the SMAD4 gene. Of note, 5 of the 6 samples with a deletion of the ACVR1B gene also had a deletion of the SMAD4 gene.
\end{abstract}

Conclusion: We identified a homozygous deletion of the ACVR1B gene in PC cell lines and clinical samples and proposed that the deletion of the ACVR1B gene may mediate an aggressive cancer phenotype in PC. Our findings provide novel insight into the role of the activin signal in PC.

Keywords: Pancreatic cancer, Activin signal, Activin A receptor, Type IB, SMAD4

\section{Background}

Pancreatic cancer (PC) is a devastating disease. Gemcitabine has been the standard therapy for experimental regimens in patients with advanced PC for over a decade, but recently, the overall survival has been significantly prolonged using combination therapies, such as gemcitabine plus erlotinib or a combination of oxaliplatin, irinotecan, fluorouracil and leucovorin (FOLFIRINOX) [1-3]. Despite some recent progress, however, the overall survival rate of patients with PC is still less than 5\% [4]. The model explaining

\footnotetext{
*Correspondence: knishio@med.kindai.ac.jp

'Department of Genome Biology, Kinki University Faculty of Medicine, 377-2

Ohno-higashi, Osaka-Sayama, Osaka 589-8511, Japan

Full list of author information is available at the end of the article
}

the progression of PC is influenced by multiple genetic alterations. During early genetic events, such as activating point mutations in the $K$-ras oncogene and the overexpression of the $H E R-2 /$ neu gene, pancreatic duct lesions show minimal cytological and architectural atypia. The inactivation of the $p 16$ tumor suppressor gene appears to occur at a later stage, followed by the loss of the $p 53$, $S M A D 4$, and BRCA2 tumor suppressor genes [5-8]. For instance, the HER-2/neu gene is not expressed in the epithelium lining of normal pancreatic duct, but it is highly expressed in pancreatic intraepithelial neoplasia [9]. However, two clinical trials assessing anit-HER2 trastuzumab

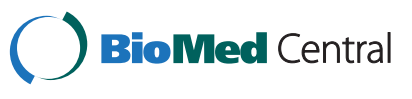

(c) 2014 Togashi et al.; licensee BioMed Central Ltd. This is an Open Access article distributed under the terms of the Creative Commons Attribution License (http://creativecommons.org/licenses/by/2.0), which permits unrestricted use, distribution, and reproduction in any medium, provided the original work is properly credited. The Creative Commons Public Domain Dedication waiver (http://creativecommons.org/publicdomain/zero/1.0/) applies to the data made available in this article, unless otherwise stated. 
therapy in patients with PC overexpressing HER2 have produced disappointing results [10,11]. Although such recent breakthroughs in the molecular biology of PC have assisted in translational research, creating hope for individualized therapy and better disease management, the inhibition of epidermal growth factor receptor using erlotinib is, to date, the only targeted approach that has been demonstrated to result in a survival [1]. Therefore, further understanding of the molecular biology of PC is needed.

The transforming growth factor, beta (TGFB) receptor II (TGFBR2) and SMAD4 genes are commonly inactivated in several types of cancer, providing evidence that the TGFB signal functions as a tumor suppressor [12,13]. Thirty percent of colorectal cancers are thought to contain a mutation in the TGFBR2 gene. The human locus 18q21, which encodes the SMAD2 and SMAD4 genes, is often mutated or lost completely in several cancers. The loss of the SMAD4 gene eliminates the classic SMAD2/ $3 / 4$ heteromeric complexes that have been implicated in a large number of TGFB-dependent transcriptional regulatory complexes. As a result, TGFB-mediated growth inhibition is lost. The SMAD4 gene is inactivated in 55\% of PC tumors, and numerous studies on TGFB signal in PC have been reported. The loss of the SMAD4 gene is correlated with both a poor prognosis and the development of widespread metastases in patients. The TGFBR2 gene is also altered in a smaller subset of PC tumors [5-7,14,15]. In addition, pancreatic-specific TGFBR2 or SMAD4-knockout mice with active $K$-ras expression developed PC $[16,17]$. However, the roles of defects other than those in the SMAD4 and TGFBR2 genes in PC remain unclear, and few studies regarding the activin signal, which also belongs to the TGFB superfamily, have been reported [18-20]. Defects in several genes involved in the activin signal pathway have been characterized in several cancers. For instance, two 8-bp polyadenine tracts in the activin A receptor, type IIA $(A C V R 2 A)$ gene were reported to be targets for frameshift mutations in gastrointestinal cancers with microsatellite instability [21]. Similarly, the activin signal induces growth inhibition and apoptosis mainly through SMAD-dependent pathways in many other cancers [22-27]. Thus, the dysregulation of the activin signal is directly involved in carcinogenesis. In contrast, however, a recent study has demonstrated that Nodal/Activin signal is associated with self-renewal and the tumorigenicity of PC stem cells [20]; thus, the role of activin signal in pancreatic carcinogenesis remains controversial. In the present study, we identified a homozygous deletion of the activin A receptor, type IB $(A C V R 1 B)$ gene in $\mathrm{PC}$ cell lines using array-comparative genomic hybridization (array-CGH). Furthermore, we investigated the role of this homozygous deletion in $\mathrm{PC}$ cell lines and the status of the $A C V R 1 B$ gene in clinical samples of PC.

\section{Results}

Identification of homozygous deletion of ACVR1B gene in PC cell lines

The results of an array-CGH demonstrated the homozygous deletion of the ACVR1B gene in the Sui65 and Sui68 cell lines (chromosome 12) and the homozygous deletion of the SMAD4 gene in the Sui65, Sui70, and Sui71 cell lines (chromosome 18) (Figure 1A and B). No deletions of other SMAD genes or other main TGFB and activin receptors, including the TGFBR1, TGFBR2, $A C V R 2 A, A C V R 2 B, S M A D 2$ genes, were found. To examine the $A C V R 1 B$ and SMAD4 gene copy numbers in the PC cell lines, we used a real-time PCR-based detection method, the TaqMan Copy Number Assay, and the experiment was performed in triplicate. The copy number results are summarized in Table 1 . The copy number of the $A C V R 1 B$ gene in the Sui68 cell line was 0 and that in the Sui65 cell line was nearly $0(0.115 \pm 0.025)$. The copy numbers of the SMAD4 gene in the Sui65, Sui70, and Sui71 cell lines were all 0 . These results were similar to those of the array-CGH.

\section{mRNA and protein expressions of ACVR1B and SMAD4 in PC cell lines}

To examine the mRNA expressions of the $A C V R 1 B$ and $S M A D 4$ genes, we performed real-time reverse transcription PCR (RT-PCR) using samples of normal pancreatic tissue from Clontech and PC cell lines. ACVR1B mRNA was scarcely expressed in the Sui65 and Sui68 cell lines, and SMAD4 mRNA was also scarcely expressed in the Sui65, Sui70, and Sui71 cell lines (Figure 2A). These results were similar to those for the array-CGH and copy number assay (Table 1). Western blot analyses were performed and showed that ACVR1B was scarcely expressed in the Sui65 and Sui68 cell lines and that SMAD4 was scarcely expressed in the Sui65, Sui70, and Sui71 cell lines. The protein expressions of ACVR1B and SMAD4 reflected the mRNA expression levels (Figure 2B).

\section{Influence of activin A on cellular growth and cell cycle in PC cell lines}

To examine the influence of ligands in the PC cell lines, we performed cellular growth assays using the Sui65 (homozygous deletion of $A C V R 1 B$ and SMAD4 genes), Sui66, Sui73 (wild-type $A C V R 1 B$ and SMAD4 genes), Sui68 (homozygous deletion of $A C V R 1 B$ gene and wildtype SMAD4 gene), and Sui70 (wild-type $A C V R 1 B$ and homozygous deletion of SMAD4 gene) cell lines in the presence of ligands. Based on numerous previous studies and our data on cellular growth inhibition [22,28], we used concentrations of $0.1,1$, or $10 \mathrm{ng} / \mathrm{mL}$ of TGFB1 or 1,10 , or $100 \mathrm{ng} / \mathrm{mL}$ of activin A. TGFB1 inhibited cellular growth in the Sui66, Sui68, and Sui73 cell lines (Figure 3B, C, and D). Activin A did not influence cellular 


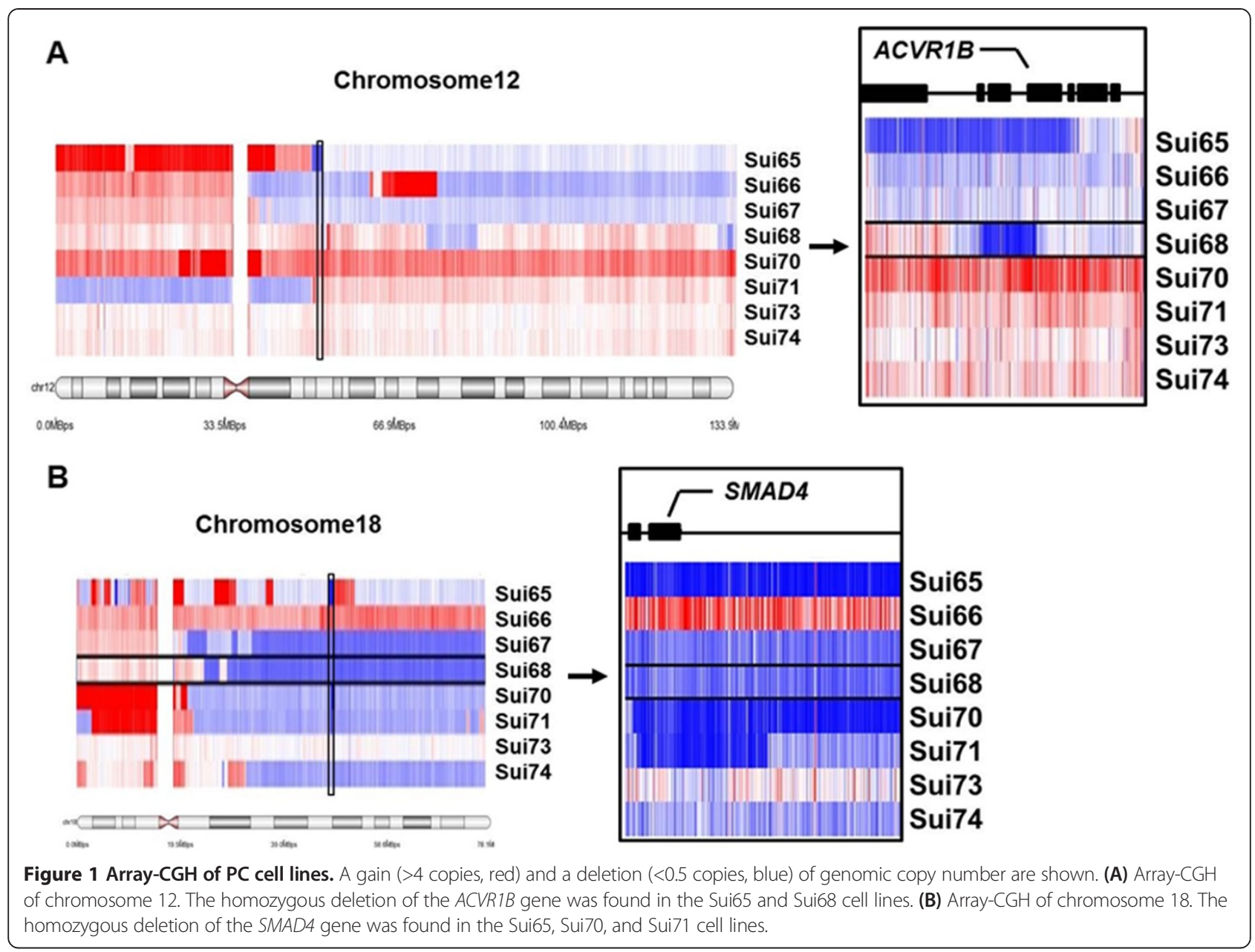

Table 1 Cell line characteristics and the status of ACVR1B and SMAD4

\begin{tabular}{|c|c|c|c|c|c|c|}
\hline \multirow{2}{*}{$\begin{array}{l}\text { Cell } \\
\text { lines }\end{array}$} & \multirow[t]{2}{*}{ Source } & \multirow[t]{2}{*}{ Histology } & \multicolumn{2}{|c|}{ ACVR1B } & \multicolumn{2}{|c|}{ SMAD4 } \\
\hline & & & $\mathrm{CN}$ & Expression & $\mathrm{CN}$ & Expression \\
\hline Sui65 & Peritoneum & Tubular & 0 & - & 0 & - \\
\hline Sui66 & Pancreas & Tubular & 1 & + & 2 & ++ \\
\hline Sui67 & Pancreas & Tubular & 1 & - & 1 & + \\
\hline Sui68 & Pancreas & $\mathrm{Ad}$ & 0 & - & 1 & + \\
\hline Sui70 & Pancreas & $\mathrm{Ad}$ & 2 & + & 0 & - \\
\hline Sui71 & Liver & $\mathrm{Ad}$ & 1 & + & 0 & - \\
\hline Sui73 & Pancreas & Tubular & 2 & + & 2 & + \\
\hline Sui74 & Pancreas & Tubular & 1 & + & 1 & - \\
\hline
\end{tabular}

ACVR1B, activin receptor A, type IB; Tubular, tubular adenocarcinoma; Ad, adenocarcinoma; $\mathrm{CN}$, gene copy number.

Legend: The copy numbers of the ACVR1B gene in the Sui65 and Sui68 cell line was 0 , and the copy numbers of the SMAD4 gene in the Sui65, Sui70, and Sui71 cell lines were all 0 . ACVR1B mRNA was scarcely expressed in the Sui65 and Sui68 cell lines, and SMAD4 mRNA was also scarcely expressed in the Sui65, Sui70, and Sui71 cell lines. These results were similar to those for the copy number assay. growth in the Sui65 and Sui68 cell lines (Figure 3A and C), although it inhibited cellular growth in the Sui66 and Sui73 cell lines (Figure 3B and D). In addition, the Sui70 cell line was not influenced by either TGFB1 or activin A (Additional file 1A).

Next, cell cycle distribution analyses were also performed. Both TGFB1 and activin A increased the proportion of cells in the G0/G1 phase and decreased the proportion of cells in the $S$ phase in the Sui66 and Sui73 cell line (Figure 4B and D). In the Sui68 cell line, however, TGFB1 increased the proportion of cells in the G0/G1 phase and decreased the proportion of cells in the $\mathrm{S}$ phase, while activin A did not affect the cell cycle distribution (Figure $4 \mathrm{C}$ ). In the Sui65 cell line, activin A did not affect the cell cycle distribution, either (Figure 4A). These results indicate that activin $\mathrm{A}$ inhibits cellular growth and induces G1 phase cell arrest in PC cell lines with wild-type $A C V R 1 B$, while activin A does not inhibit cellular growth and does not influence the cell cycle in cell lines with a homozygous deletion of the $A C V R 1 B$ gene. 


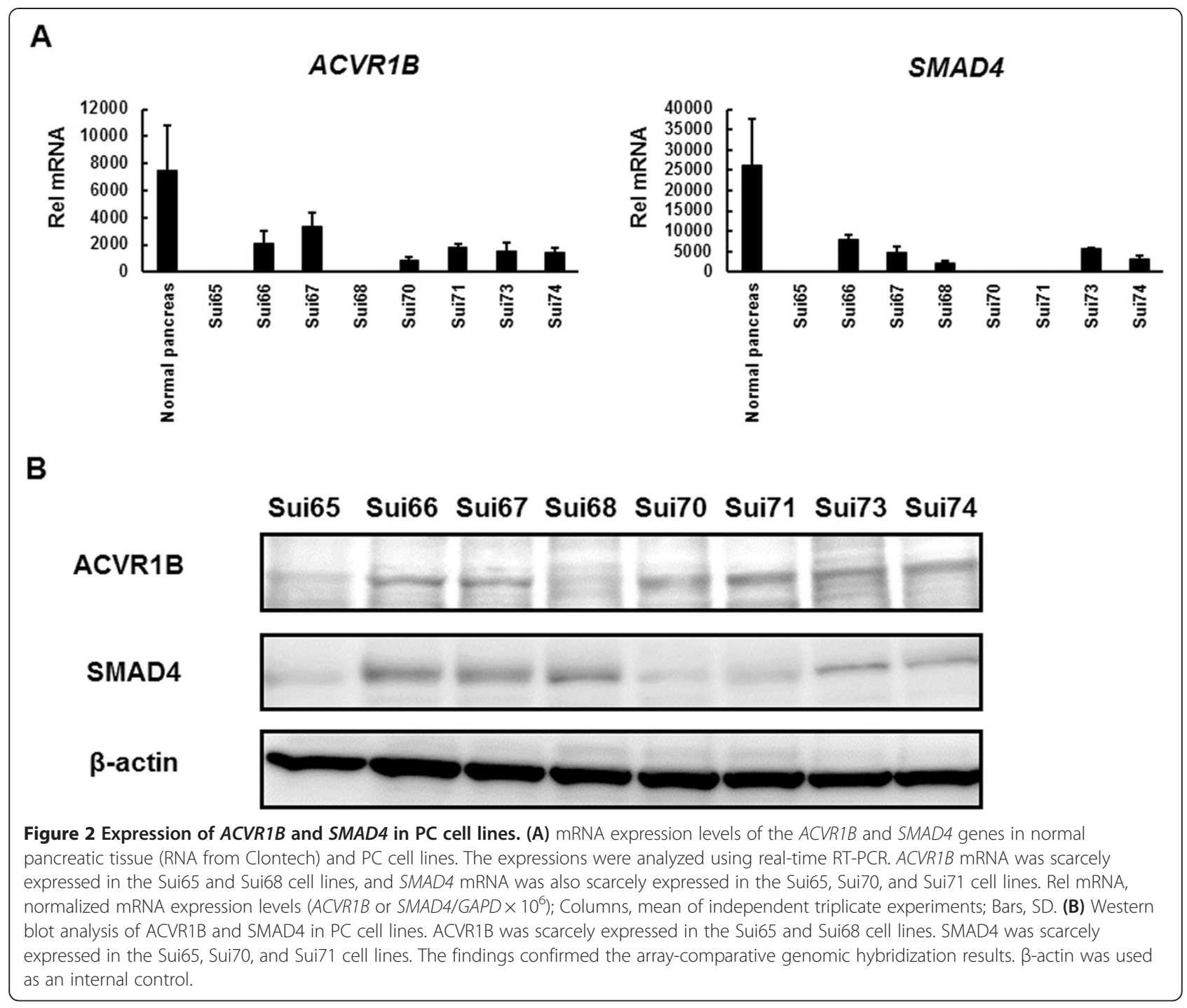

Effect of activin A on SMAD2 phosphorylation and p21 induction in $\mathrm{PC}$ cell lines

Activin A inhibited the cellular growth of cell lines with wild-type $A C V R 1 B$ and SMAD4 genes; therefore, we examined the downstream signal under TGFB1 or activin A stimulation. Based on numerous previous studies and our data on cellular growth inhibition [22,28], we used $1 \mathrm{ng} / \mathrm{mL}$ of TGFB1 or $10 \mathrm{ng} / \mathrm{mL}$ of activin A. The time points were also decided based on the previous studies $[22,28]$. In the Sui66 cell line (wild-type $A C V R 1 B$ and $S M A D 4$ genes), both TGFB1 and activin A increased the phosphorylation levels of SMAD2 (Figure 5A); these effects were cancelled by the ACVR1B/TGFBR1/ACVR1Cspecific inhibitor SB431542 (Figure 5C). In the Sui68 cell line (homozygous deletion of $A C V R 1 B$ gene and wild-type $S M A D 4$ gene), TGFB1, but not activin $\mathrm{A}$, increased the phosphorylation levels of SMAD2 (Figure 5A); these effects were cancelled by SB431542 (Figure 5C). These results suggest that activin A activates the SMAD signal in a manner similar to TGFB1 in PC cell lines with the wildtype $A C V R 1 B$ gene, but does not activate in PC cell lines with the homozygous deletion of the $A C V R 1 B$ gene.

Next, we evaluated the expression levels of p $21^{\text {CIP1/WAF1 }}$ $\mathrm{p} 21^{\mathrm{CIP} 1 / \mathrm{WAF} 1}$ is a major cdk inhibitor and is a hallmark of the cytostatic role of the TGFB signal pathway [29]. TGFB and activin A are known to increase p21 expression $[22,28]$. The expression of p21 was evaluated in whole-cell lysates. p21 expression was increased by both TGFB1 and activin A in the Sui66 cell line. In the Sui68 cell line, however, its expression was increased only by TGFB1 (Figure 5B). Therefore, we speculated that p21 may have a role in activin A-mediated growth inhibition and cellcycle progression.

To evaluate the effect of activin A on SMAD4-independent pathways, the phosphorylation of ERK $1 / 2$ and AKT, which are representative signals of SMAD4-independent pathways, was investigated in the Sui70 cell line (wild-type $A C V R 1 B$ and homozygous deletion of SMAD4 genes). 


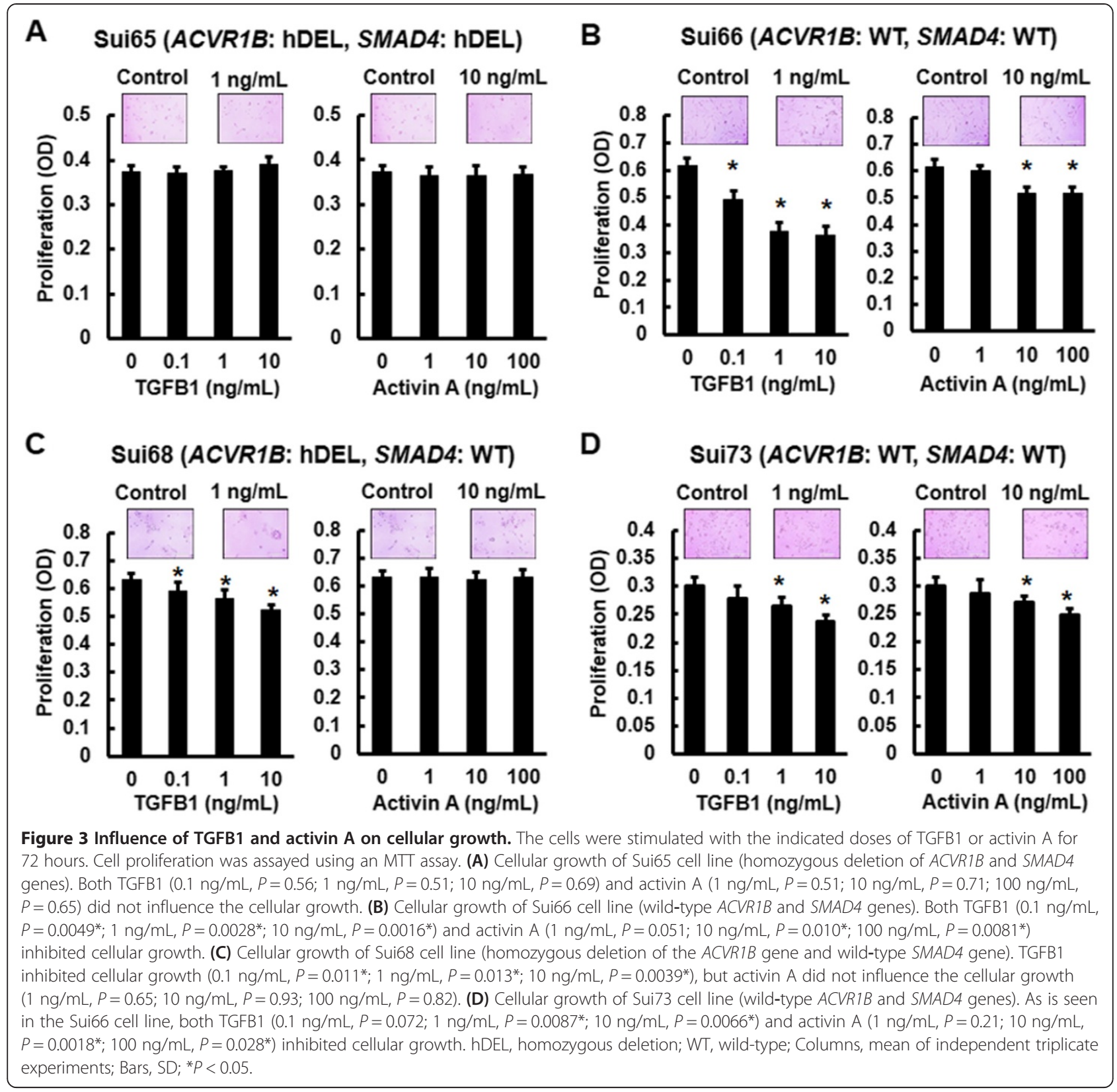

The phosphorylation was not changed by activin A (Additional file 1B). Particularly, both AKT and ERK1/2 were phosphorylated before the stimulations. The expression of p21 also remained unchanged.

Enhanced cellular growth and colony formation, but no response to activin A, of Sui66/shACVR1B and Sui73/shACVR1B cell lines

To evaluate the role of the $A C V R 1 B$ gene, we examined the colony formation and the cellular growth of stable ACVR1B-knockdown cell lines (Sui66/shACVR1B-1, Sui66/shACVR1B-2, Sui73/shACVR1B-1, and Sui73/ shACVR1B-2) or control cell lines (Sui66/shScr-1, Sui66/
shScr-2, Sui73/shScr-1, and Sui73/shScr-2) (Figure 6A). Activin A did not increase the phosphorylation level of SMAD2 in the Sui66/shACVR1B-1, Sui66/shACVR1B-2, Sui73/shACVR1B-1, or Sui73/shACVR1B-2 cell lines (Figure 6A). Although activin A inhibited the cellular growth of the Sui66/shScr-1, Sui66/shScr-2, Sui73/shScr-1, and Sui73/shScr-2 cell lines, it did not influence the cellular growth of the Sui66/shACVR1B-1, Sui66/shACVR1B-2, Sui73/shACVR1B-1, or Sui73/shACVR1B-2 cell lines (Figure 6B). The colony formation and cellular growth of the Sui66/shACVR1B-1, Sui66/shACVR1B-2, Sui73/ shACVR1B-1, and Sui73/shACVR1B-2 cell lines were also enhanced, compared with the controls (Figure 6C and D). 
A

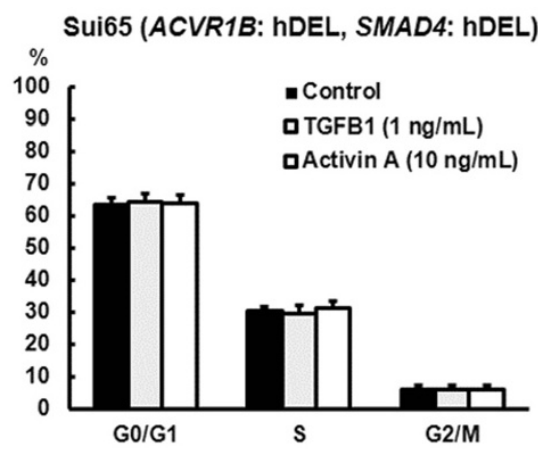

C

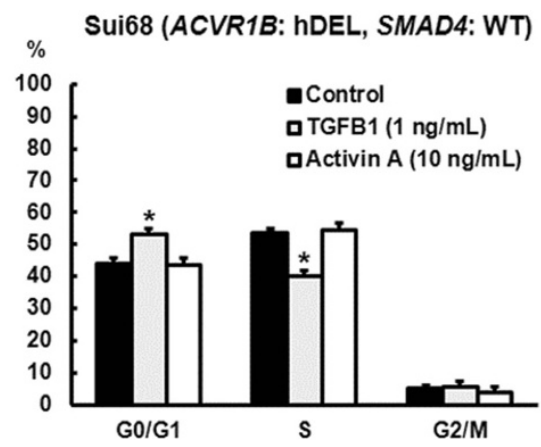

B

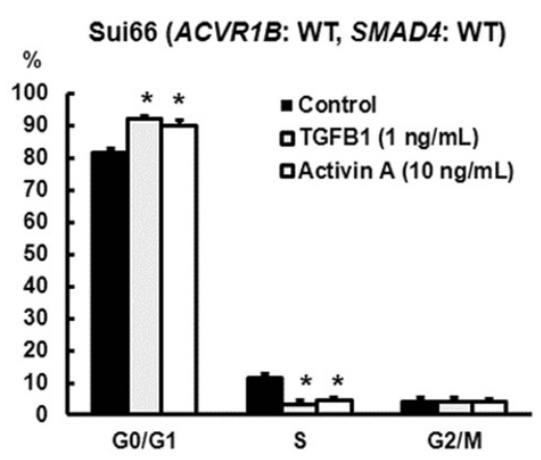

D

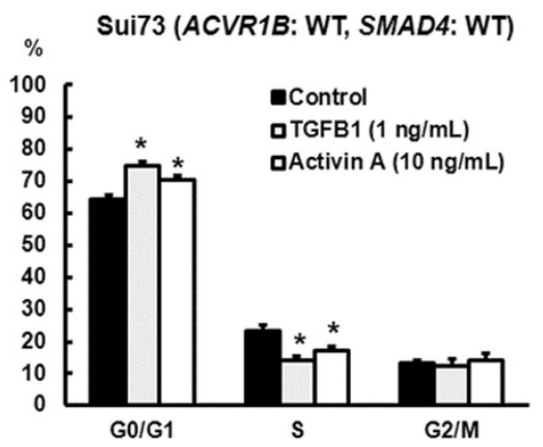

Figure 4 Influence of TGFB1 and activin A on the cell cycle. The cell lines were exposed to the ligands (TGFB1, $1 \mathrm{ng} / \mathrm{mL} ; \mathrm{activin} \mathrm{A,} 10 \mathrm{ng} / \mathrm{mL}$ ) for 48 hours. The cells were then stained using propidium iodide/RNase Staining Buffer and were analyzed using a flow cytometer. (A) Cell cycle distribution of Sui65 cell line (homozygous deletion of ACVR1B and SMAD4 genes). Both TGFB1 and activin A did not influence the cell cycle distribution. (B) Cell cycle distribution of Sui66 cell line (wild-type ACVR1B and SMAD4 genes). Both TGFB1 and activin A increased the proportion of cells in $\mathrm{G} 0 / \mathrm{G} 1$ phase $\left(P=0.0039^{*}\right.$ and $0.031^{*}$, respectively) and decreased the proportion of cells in $\mathrm{S}$ phase $\left(P=0.0043^{*}\right.$ and $0.039^{*}$, respectively). (C) Cell cycle distribution of Sui68 cell line (homozygous deletion of the ACVR1B gene and wild-type SMAD4 gene). TGFB1 increased the proportion of cells in $\mathrm{G} 0 / \mathrm{G} 1$ phase $\left(P=0.0016^{*}\right)$ and decreased the proportion of cells in S phase $\left(P=0.019^{*}\right)$, while activin A did not influence the cell cycle distribution. (D) Cell cycle distribution of Sui73 cell line (wild-type ACVR1B and SMAD4 genes). As is seen in the Sui66 cell line, both TGFB1 and activin A increased the proportion of cells in G0/G1 phase $\left(P=0.014^{*}\right.$ and $0.039^{*}$, respectively) and decreased the proportion of cells in S phase $\left(P=0.0034^{*}\right.$ and $0.0021^{*}$, respectively). hDEL, homozygous deletion; WT, wild-type; Columns, mean of independent triplicate experiments; Bars, SD; ${ }^{*}<0.05$.

These results indicate that the $A C V R 1 B$ gene is involved in tumorigenicity and cellular growth.

\section{Enhanced in vivo tumorigenicity and tumor growth of stable ACVR1B-knockdown cell lines}

We evaluated the in vivo tumorigenicity of Sui66transfectant cell lines and the tumor growth of Sui73transfectant cell lines. Sui66/shACVR1B exhibited a significantly elevated level of tumorigenesis (Sui66/shScr-1 $1 / 14$ vs. Sui66/shACVR1B-1 8/14, $P=0.013$ and Scr-2 2/ 14 vs. ACVR1B-2 10/14, $\left.P=0.0063^{*}\right)$, and Sui73/shACVR1B exhibited a larger tumor volume than Sui73/shScr (Sui73/ Scr-1, $167.7 \pm 59.1 \mathrm{~mm}^{3}$ vs. Sui73/ACVR1B-1, $275.0 \pm$ $56.3 \mathrm{~mm}^{3} ; P=0.018^{*}$ on day 36 and Sui73Scr-2, $105.7 \pm$ $27.2 \mathrm{~mm}^{3}$ vs. Sui73/ACVR1B-2, $217.3 \pm 81.8 \mathrm{~mm}^{3} ; P=$ $0.020^{*}$ on day 29 , respectively). (Figure $7 \mathrm{~A}$ and B). There was no significant difference in body weight (Sui73/Scr-1, $24.3 \pm 1.0$ g vs. Sui73/ACVR1B-1, $23.24 \pm 1.5$ g; $P=0.22$ on day 36 and Sui73/Scr-2, $21.6 \pm 1.3$ g vs. Sui73/ ACVR1B-2, $21.1 \pm 1.8 \mathrm{~g} ; P=0.61$ on day 29 , respectively).
According to western blot analyses of the tumors and immunostaining, the expressions of p21 were clearly elevated in the cancer cells in the shScr-inoculated tumors, compared with the expression levels in the shACVR1B cells (Figure 7C). In addition, the expressions of Ki67 were clearly elevated in the cancer cells in the shACVR1B-inoculated tumors (Figure 7C). These results indicate that the $A C V R 1 B$ gene is involved in tumorigenicity and tumor growth and that it downregulated the expression level of p21 in cancer cells in vivo, similar to its effect in vitro.

Suppressed in vitro cellular growth and colony formation, and in vivo tumorigenicity of p21-overexpressed Sui68 cell line

To determine whether $\mathrm{p} 21$ expression reverses the phenotype of the $A C V R 1 B$ gene homozygous deletion, we created a p21-overexpressed Sui68 cell line (homozygous deletion of $A C V R 1 B$ gene and wild-type SMAD4 gene) (Figure 8A). The colony formation and cellular growth of 


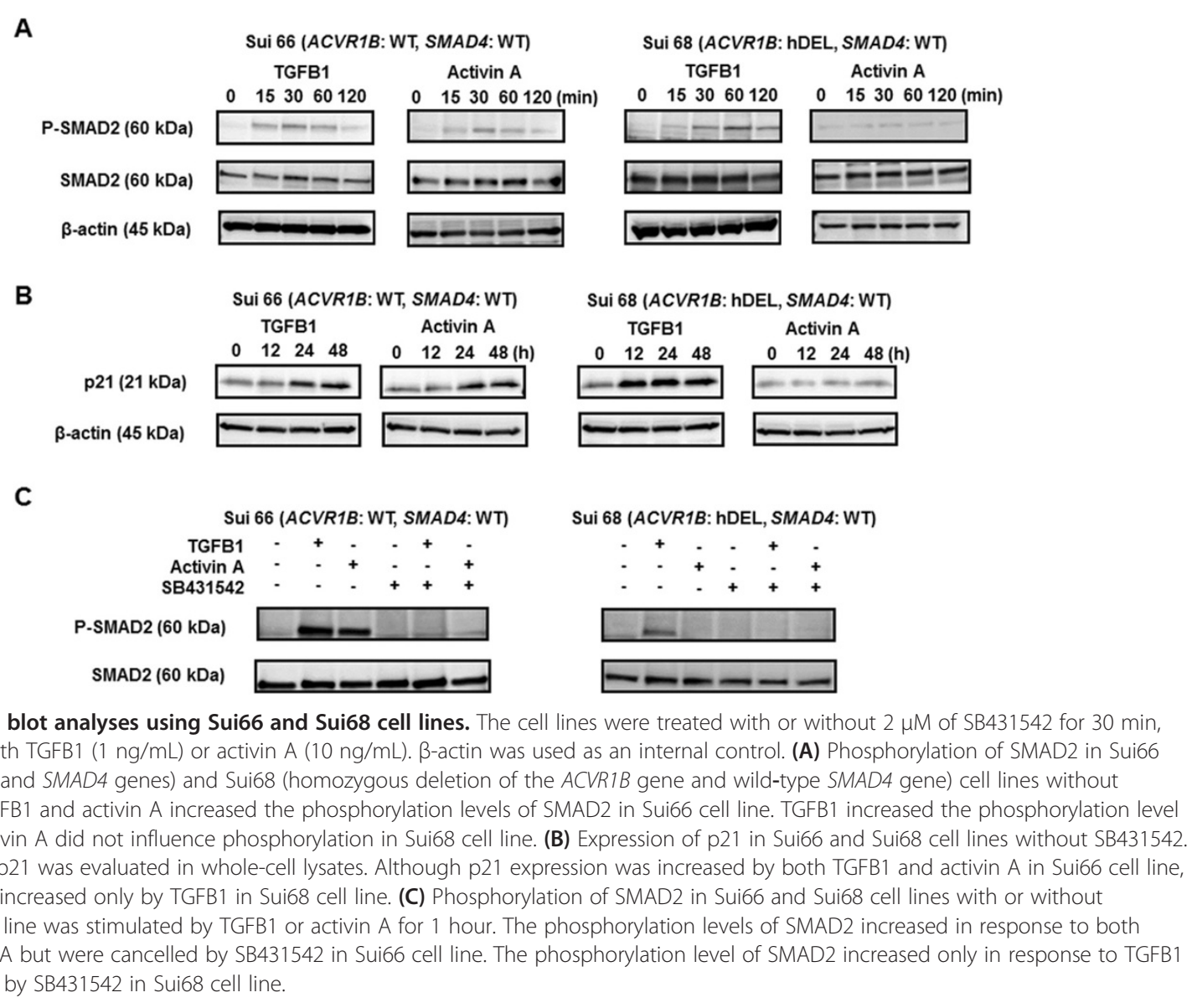

the Sui68/p21 cell line were greatly suppressed, compared with the controls (Figure 8B and C). In addition, Sui68/ EGFP exhibited a significantly elevated level of tumorigenesis (Sui68/EGFP 14/14 vs. Sui68/p21 8/14, $P=0.016$ ), and Sui68/EGFP exhibited a larger tumor volume than Sui68/p21 on day 15 (Sui68/EGFP, $507.0 \pm 83.5 \mathrm{~mm}^{3}$ vs. Sui68/p21, $276.5 \pm 95.0 \mathrm{~mm}^{3} ; P=0.0036^{*}$ ) (Figure 8D). No significant difference in body weight was seen on day 15 (Sui68/EGFP, $20.3 \pm 0.8$ g vs. Sui68/p21, $20.2 \pm$ $1.5 \mathrm{~g} ; P=0.94)$. These results suggest that $\mathrm{p} 21$ expression reverses the phenotype arising from the homozygous deletion of the $A C V R 1 B$ gene.

\section{ACVR1B and SMAD4 gene copy numbers in clinical samples of $\mathrm{PC}$}

To examine the ACVR1B and SMAD4 gene copy numbers in PC clinical samples, we performed a TaqMan Copy Number Assay. The ACVR1B gene copy numbers in 6 samples $(6 / 29,20.7 \%)$ were less than 0.5 (Figure 9A), while the SMAD4 gene copy numbers in 10 samples $(10 / 29,34.5 \%)$ were less than 0.5 (Figure 9A). The association between the patient characteristics and the $A C V R 1 B$ gene status is summarized in Table 2. Interestingly, 5 of the 6 samples with a deletion of the $A C V R 1 B$ gene also had a deletion of the SMAD4 gene $(P=0.011)$, but no significant differences in the other patient characteristics were observed between the two groups. According to the immunostaining results, the expressions of p21 were clearly elevated in the cancer cells of patients with wild-type $A C V R 1 B$ and SMAD4 genes, compared with the expression levels in patients with the homozygous deletion of the $A C V R 1 B$ gene (Figure 9B). Twentyone patients with a good performance status received chemotherapy (gemcitabine, $\mathrm{n}=12$; gemcitabine $/ \mathrm{S} 1, \mathrm{n}=5$; S1, $\mathrm{n}=4$ ) at Kinki University Hospital. These regimens were commonly used in Japan before the availability of erlotinib or FOLFIRINOX. Among these patients, no significant differences in progression-free survival (PFS) or overall survival (OS) were seen between the two groups (Figure 9C and Table 2).

\section{Discussion}

In this study, we identified a homozygous deletion of the $A C V R 1 B$ gene in PC cell lines and clinical samples. Activin A inhibited cellular growth in the cell lines with wild-type $A C V R 1 B$ and SMAD4 genes, and ACVR1Bknockdown enhanced cellular growth and colony formation in vitro as well as tumor growth and tumorigenicity 


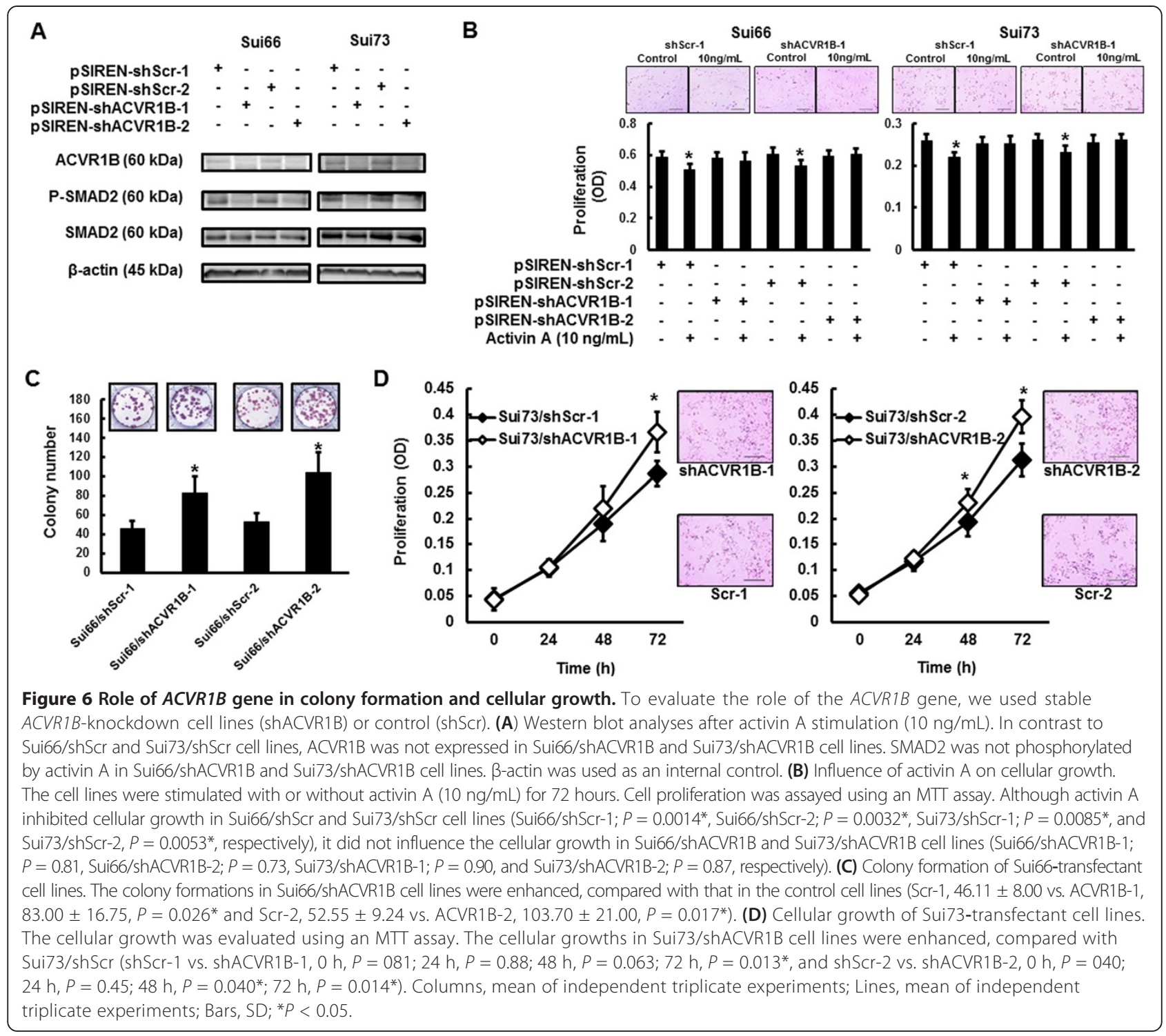

in vivo. These results suggest that the activin signal has a tumor suppressive role in $\mathrm{PC}$ and that the deletion of the $A C V R 1 B$ gene mediates an aggressive cancer phenotype relative to PC carrying the wild-type $A C V R 1 B$ gene.

Similar to our study, several articles have shown an anti-tumorigenic effect of the activin signal. Activin A induces growth inhibition and apoptosis mainly through SMAD-dependent pathways in many other cancers, such as gall bladder cancer, prostate cancer, neuroblastoma, breast cancer, ovarian cancer, and colon cancer [22-27]. In our study, activin A inhibited cellular growth and induced G1 phase cell arrest in a PC cell line with wild-type $A C V R 1 B$ and SMAD4 genes via the phosphorylation of SMAD2 and the expression of p21, while the cellular growth of a cell line with the homozygous deletion of the $A C V R 1 B$ gene was not inhibited by activin A. In addition, the cellular inhibitory effect of activin A and the activin- induced phosphorylation of SMAD2 were cancelled by $A C V R 1 B$-knockdown in cell lines with wild-type $A C V R 1 B$ and SMAD4 genes. In vivo, $A C V R 1 B$-knockdown also enhanced the tumorigenicity and tumor growth. The Sui68 cell line (homozygous deletion of the ACVR1B gene and the wild-type SMAD4 gene) was capable of generating sufficient tumors, suggesting that the deletion of the $A C V R 1 B$ gene contributes to tumorigenicity even in the presence of the wild-type SMAD4 gene. In addition, the in vitro colony formation and cellular growth and the in vivo tumorigenicity of the Sui68 cell line were greatly inhibited by $p 21$-overexpression. Thus, the antitumorigenic effect of the activin signal via the SMAD pathways and p21 was lost by $A C V R 1 B$-knockdown, which was related to an aggressive phenotype of PC.

Interestingly, another article and the present study both demonstrated that the inactivation of the $A C V R 1 B$ 


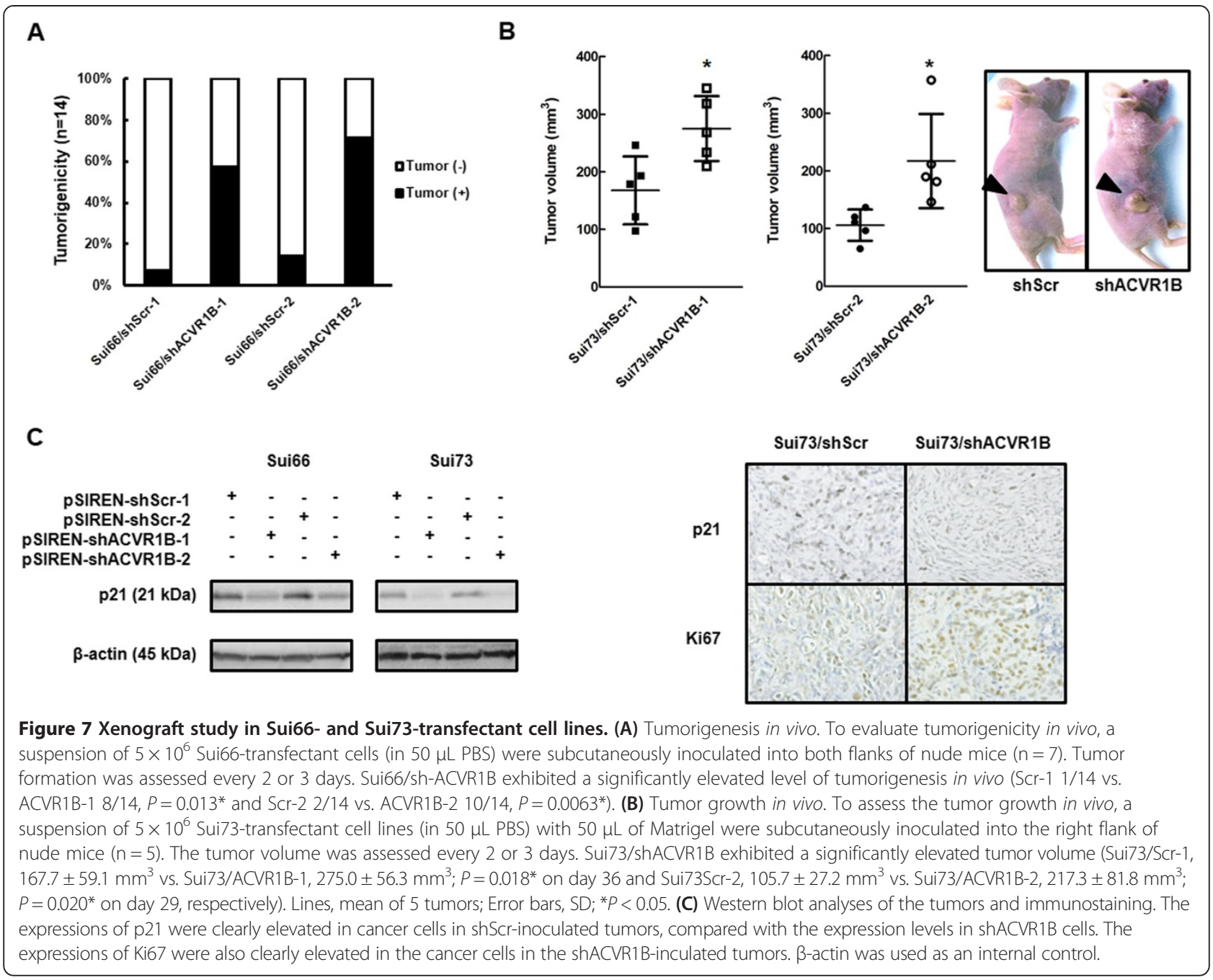

gene is frequently complicated by the inactivation of the SMAD4 gene [19]. The TGFB and activin signals have non-SMAD pathways, and the ERK/MAPK signal and the PI3K/AKT signal are representative signals that are associated with cellular growth and survival [30]. In the Sui70 cell line (wild-type $A C V R 1 B$ gene and the homozygous deletion of the SMAD4 gene), however, activin A did not influence the cellular growth, and neither the phosphorylation of ERK1/2 nor that of AKT was enhanced. Approximately $95 \%$ of PC, including the Sui70 cell line has a K-ras mutation [5-8], and both ERK1/2 and AKT are phosphorylated in the Sui70 cell line because of this mutation [31]. Therefore, non-SMAD pathways may have little effect on the aggressiveness of PC carrying the wild-type $A C V R 1 B$ gene and a homozygous deletion of the SMAD4 gene. In addition, some other reports have suggested that the inactivation of a TGFB receptor is not mutually exclusive with that of the SMAD4 gene, since both members are known to be genetically inactivated in some tumors [32,33]. Therefore, these findings would fit with a combined input model, which could explain the observed coexistence of the genetic inactivations of these genes.

Pancreatic-specific TGFBR2 or SMAD4-knockout mice with active $K$-ras expression reportedly developed PC $[16,17]$. However, systemic $A C V R 1 B$-knockout mice do not survive beyond embryonic day 9.5 [34], and pancreaticspecific $A C V R 1 B$-knockout mice have not been previously studied. Considering the tumor suppressive role of the $A C V R 1 B$ gene, the development of PC in pancreaticspecific $A C V R 1 B$-knockout mice seems reasonable. In contrast to our results, however, a recent study has demonstrated that Nodal/Activin signal is associated with self-renewal and the tumorigenicity of PC stem cells [20]. Therefore, to investigate these findings, further research is required.

Since the clinical DNA samples were obtained using needle biopsies, the inclusion of some normal pancreas tissue was unavoidable. Thus, the copy number data does not exactly reflect that for cancer tissue. In addition, the 

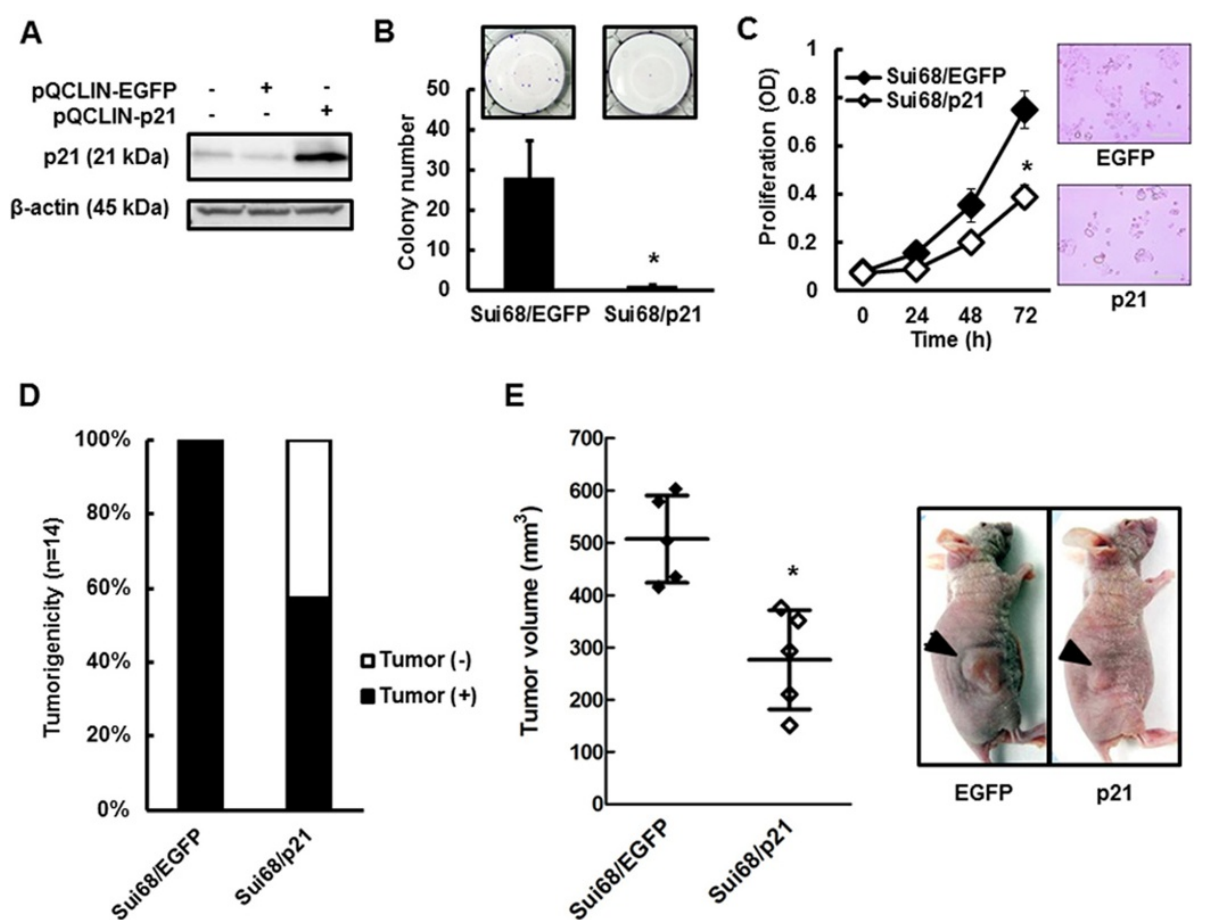

Figure 8 Role of $p 21$ gene in colony formation and cellular growth in vitro and tumorigenicity in vivo. To see if p21 expression reverses the phenotype for ACVR1B gene homozygous deletion, we created a p21-overexpressed Sui68 cell line (homozygous deletion of ACVR1B gene and wild-type SMAD4 gene). (A) Western blot analyses. The overexpression of p21 was confirmed using western blot analyses in the Sui68/p21 cell line. $\beta$-actin was used as an internal control. (B) Colony formation of Sui68-transfectant cell lines. The colony formation in the Sui68/p21 cell line was suppressed, compared with that in the control cell line (EGFP, $28.0 \pm 9.17 \mathrm{vs.}$. $21,0.89 \pm 0.19, P=0.035^{*}$ ). Columns, mean of independent triplicate experiments; Bars, SD; $* P<0.05$. (C) Cellular growth of Sui68-transfectant cell lines. The cellular growth was evaluated using an MTT assay. Cellular growth in the Sui68/p21 cell line was suppressed, compared with Sui68/EGFP ( $\left.0 \mathrm{~h}, P=065 ; 24 \mathrm{~h}, P=0.074 ; 48 \mathrm{~h}, P=0.053 ; 72 \mathrm{~h}, P=0.030^{*}\right)$. Lines, mean of independent triplicate experiments; Bars, SD; ${ }^{*} P<0.05$. (D) Tumorigenesis in vivo. To evaluate tumorigenicity in vivo, a suspension of $5 \times 10^{6}$ Sui68-transfectant cells (in $50 \mu \mathrm{LPBS}$ ) were subcutaneously inoculated into both flanks of nude mice $(\mathrm{n}=7)$. Sui68/EGFP exhibited a significantly elevated level of tumorigenesis (Sui68/EGFP 14/14 vs. Sui68/p21 8/14, $P=0.016$ ). (E) Tumor growth in vivo. To evaluate the tumor growth, a suspension of $5 \times 10^{6}$ Sui68-transfectant cells (in $50 \mu \mathrm{L}$ PBS) with $50 \mu \mathrm{L}$ of Matrigel were subcutaneously inoculated into the right flanks of nude mice $(\mathrm{n}=5$ ). Sui68/EGFP exhibited a larger tumor volume than Sui68/p21 on day 15 (Sui68/EGFP, $507.0 \pm 83.5 \mathrm{~mm}^{3}$ vs. Sui68/p21, 276.5 $\pm 95.0 \mathrm{~mm}^{3} ; P=0.0036 *$ ). Lines, mean of five tumors; Bars, SD; ${ }^{*} P<0.05$.

number of clinical samples was very small. Therefore, this cohort has many limitations. No significant differences in the PFS or OS were observed between the patients with $A C V R 1 B$ gene deletions and those without. To confirm the clinical importance of the $A C V R 1 B$ gene deletion, larger studies including more precise genome evaluations are needed.

\section{Conclusion}

We identified the homozygous deletion of the $A C V R 1 B$ gene in PC cell lines and clinical samples. Our experimental findings indicate that the activin signal has a tumor suppressive role and that the deletion of the ACVR1B gene may mediate an aggressive cancer phenotype in PC.

\section{Materials and methods}

Cell culture, ligands, and reagents

Human PC cell lines (Sui65, Sui66, Sui67, Sui68, Sui70, Sui71, Sui73, and Sui74) were maintained in RPMI-1640 medium (Sigma-Aldrich, St. Louis, MO) with 10\% FBS (GIBCO BRL, Grand Island, NY) (Table 1) [31]. The cell lines were maintained in a $5 \% \mathrm{CO}_{2}$-humidified atmosphere at $37^{\circ} \mathrm{C}$.

TGFB1 and activin A were both purchased from R\&D Systems (Minneapolis, MN). The ACVR1B/TGFBR1/ ACVR1C-specific inhibitor SB431542 was purchased from Sigma-Aldrich.

\section{Array-based comparative genomic hybridization}

The Genome-wide Human SNP Array 6.0 (Affymetrix, Santa Clara, CA) was used to perform array-CGH on genomic DNA from each of the PC cell lines as described previously [35]. The GeneChip Human Mapping $250 \mathrm{~K}$ Nsp Array (Affymetrix) was used to perform array-CGH on genomic DNA from each of the cell lines. A total of 250 ng of genomic DNA was digested with Nsp I (250 K) or both Nsp I and Sty I in independent parallel reactions (SNP6.0), subjected to restriction enzymes, ligated to the 
A

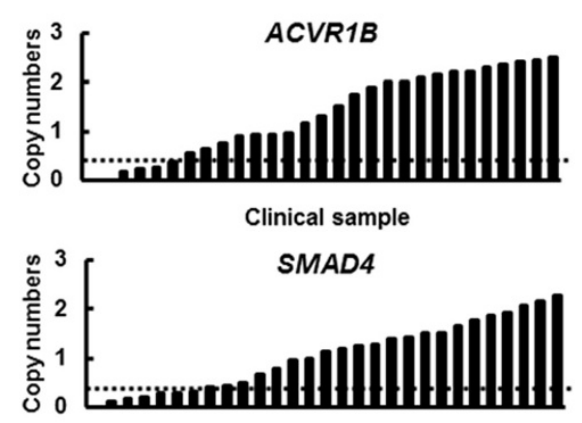

Clinical sample

C

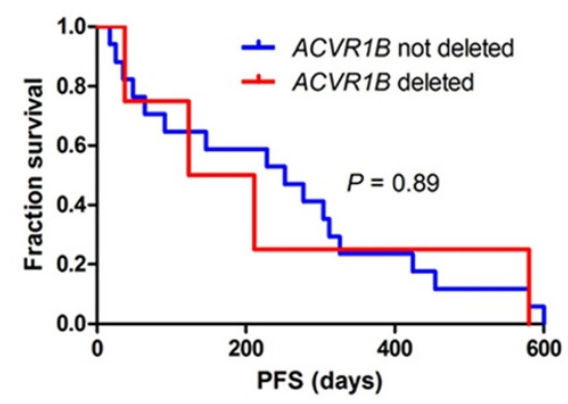

B
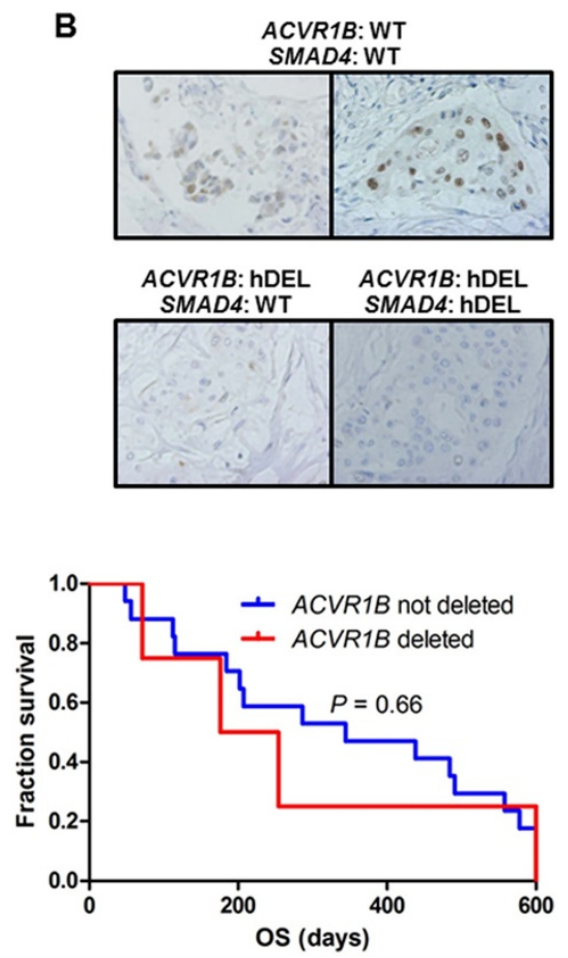

Figure 9 Copy numbers of ACVR1B and SMAD4 genes, immunostaining of p21, and Kaplan-Meier curves for PFS and OS in PC clinical samples. (A) The copy numbers were analyzed using TaqMan copy number assays. Copy number of the ACVR1B gene. Six samples (6/29, 20.7\%) had a copy number of less than 0.5 (deletion). Copy number of the SMAD4 gene. Ten samples $(10 / 29,34.5 \%$ ) had a copy number of less than 0.5 (deletion). (B) Immunostaining of p21. The expressions of p21 were clearly elevated in the cancer cells of patients with wild-type $A C V R 1 B$ and SMAD4 genes, compared with the expression levels in those of patients with a homozygous deletion of the ACVR1B gene. WT, wild-type; hDEL, homozygous deletion. (C) Kaplan-Meier curves for PFS and OS. Among 21 patients who received chemotherapy, no significant differences in PFS or OS were seen between the patients without a homozygous deletion of the ACVR1B gene and those with such a deletion (median PFS, 252 days vs. 167 days, $\mathrm{P}=0.89$, and median OS, 344 days vs. 215 days, $\mathrm{P}=0.66$, respectively).

adaptor, and amplified using PCR with a universal primer and TITANIUM Taq DNA Polymerase (Clontech, Palo Alto, CA). The PCR products were then quantified, fragmented, end-labeled, and hybridized onto a GeneChip Human Mapping $250 \mathrm{~K}$ Nsp Array or a Genome-wide Human SNP6.0 Array. After washing and staining in Fluidics Station 450 (Affymetrix), the arrays were scanned to generate CEL files using the GeneChip Scanner 3000 and GeneChip Operating Software, ver.1.4.

\section{Copy number assay for ACVR1B and SMAD4 genes}

The copy numbers for $A C V R 1 B$ and SMAD4 genes were determined using commercially available and pre-designed TaqMan Copy Number Assays (Applied Biosystems, Foster City, CA) as described previously [36]. The primer IDs used for the ACVR1B and SMAD4 genes were Hs06931689_cn (intron 1) and Hs07120826_cn (intron 1), respectively. The TERT locus was used for the internal reference copy number. Human Genomic DNA (TaKaRa) was used as a normal control. Real-time genomic PCR was performed in a total volume of $20 \mu \mathrm{L}$ in each well, which contained $10 \mu \mathrm{L}$ of TaqMan genotyping master mix and $20 \mathrm{ng}$ of genomic
DNA and each primer. The PCR conditions were $95^{\circ} \mathrm{C}$ for $10 \mathrm{~min}$ and 40 cycles of $95^{\circ} \mathrm{C}$ for $15 \mathrm{sec}$ and $60^{\circ} \mathrm{C}$ for $1 \mathrm{~min}$; the resulting products were detected using the ABI PRISM 7900 HT Sequence Detection System (Applied Biosystems). Data were analyzed using SDS 2.2 software and CopyCaller software (Applied Biosystems). Samples with a gene copy number of less than 0.5 were defined as having a copy number of 0 (deletion of the gene), while those with a gene copy number of 0.5 or more but less than 1.5 were defined as having a copy number of 1 and those with a gene copy number of 1.5 or more but less than 2.5 were defined as having a copy number of 2 .

\section{Real-time RT-PCR}

One microgram of total RNA from each of the PC cell lines and normal pancreas tissue purchased from Clontech were converted to cDNA using the GeneAmp RNA-PCR kit (Applied Biosystems). Real-time PCR was performed using the Applied Biosystems 7900 HT Fast Real-time PCR System (Applied Biosystems), as described previously [28] under the following conditions: 
Table 2 Patient characteristics and the association with ACVR1B gene status

\begin{tabular}{|c|c|c|c|}
\hline \multirow[t]{2}{*}{ Patients characteristics } & \multicolumn{2}{|l|}{ ACVR1B gene } & \multirow[t]{2}{*}{$P$} \\
\hline & $\begin{array}{l}\text { Not deletion } \\
(n=23)\end{array}$ & $\begin{array}{l}\text { Deletion } \\
(n=6)\end{array}$ & \\
\hline \multicolumn{4}{|l|}{ Age } \\
\hline$<70$ years & 15 & 3 & 0.65 \\
\hline$\geq 70$ years & 8 & 3 & \\
\hline \multicolumn{4}{|l|}{ Gender } \\
\hline Male & 12 & 3 & 1.00 \\
\hline Female & 11 & 3 & \\
\hline \multicolumn{4}{|l|}{ Primary size } \\
\hline$<2 \mathrm{~cm}$ & 18 & 5 & 1.00 \\
\hline$\geq 2 \mathrm{~cm}$ & 5 & 1 & \\
\hline \multicolumn{4}{|l|}{ Lymph node metastasis } \\
\hline Negative & 4 & 0 & 0.55 \\
\hline Positive & 19 & 6 & \\
\hline \multicolumn{4}{|l|}{ Distant metastasis } \\
\hline Negative & 10 & 4 & 0.39 \\
\hline Positive & 13 & 2 & \\
\hline \multicolumn{4}{|l|}{ SMAD4 gene status } \\
\hline Not deletion & 18 & 1 & $0.011^{*}$ \\
\hline Deletion & 5 & 5 & \\
\hline \multicolumn{4}{|l|}{ Treatment } \\
\hline Best supportive care & 4 & 2 & 0.59 \\
\hline Chemotherapy & 17 & 4 & \\
\hline Unknown & 2 & 0 & \\
\hline \multicolumn{4}{|l|}{ Response to chemotherapy } \\
\hline$P R$ & 7 & 1 & 1.00 \\
\hline SD or PD & 10 & 3 & \\
\hline Median PFS (days) & 252 & 167 & 0.89 \\
\hline Median OS (days) & 344 & 215 & 0.66 \\
\hline
\end{tabular}

ACVR1B, activin receptor A, type IB; PR, partial response; SD, stable disease; PD, progressive disease; PFS, progression-free survival; OS, overall survival. PFS and OS were analyzed by log-rank test and the others by Fisher exact test. Legend: Six patients $(6 / 29,20.7 \%)$ had a deletion of $A C V R 1 B$ gene, 10 patients $(10 / 29,34.5 \%)$ had a deletion of SMAD4 gene. Five of the 6 patients with a deletion of the ACVR1B gene also had a deletion of the SMAD4 gene $(P=0.011)$, but no significant differences in the other patient characteristics were observed between the two groups. Among 21 patients who received chemotherapy, no significant differences in PFS or OS were seen between the two groups.

$95^{\circ} \mathrm{C}$ for $5 \mathrm{~min}, 50$ cycles of $95^{\circ} \mathrm{C}$ for $10 \mathrm{sec}$, and $60^{\circ} \mathrm{C}$ for $1 \mathrm{~min}$. Glyceraldehyde 3 phosphate dehydrogenase (GAPD, NM_002046) was used to normalize the expression levels in subsequent quantitative analyses. To amplify the target genes, the following primers were used: ACVR1B-F, CAGCAGAACCTTGGCGGTTTA; ACVR1BR, GTTGGCAGATCCCAGAGGCTAC; SMAD4-F, CAG CTATGCCAGAAGCCAGA; SMAD4-R, GAACTCCTGG GACTTTCAACTGAC; GAPD-F, GCACCGTCAAGGCT
GAGAAC; GAPD-R, ATGGTGGTGAAGACGCCAGT. The experiment was performed in triplicate.

\section{Plasmid construction, viral production, and stable transfectants}

A short hairpin RNA (shRNA)-targeting $A C V R 1 B$ gene was constructed using oligonucleotides encoding small interfering RNA directed against the $A C V R 1 B$ gene and a non-specific target as follows: GAATTGCTCATCGAGACTT and GGCTTGTTTCTGACTATCA for ACVR1B shRNA (shRNA ACVR1B-1 and shRNA ACVR1B-2, respectively), and ACTTGGTTCGCGTATCAAA and CCA TATTGCGCGTTGATTT for control shRNA (shRNA scramble-1 and shRNA scramble-2, respectively). The method was described previously [28]. Briefly, the oligonucleotides were cloned into an RNAi-Ready pSIRENRetroQZsGreen vector (Clontech). A pVSV-G vector (Clontech) for the constitution of the viral envelope and the RNAi-Ready pSIREN-RetroQZsGreen constructs were cotransfected into gpIRES-293 cells using FuGENE6 transfection reagent (Roche Diagnostics, Basel, Switzerland). After 48 hours of transfection, the culture medium was collected and the viral particles were concentrated by centrifugation at $15,000 \times g$ for 3 hours at $4^{\circ} \mathrm{C}$. The viral pellet was then resuspended in fresh RPMI-1640 medium. The titer of the viral vector was calculated by counting the green-positive cells that were infected by serial dilutions of virus-containing media, and the multiplicity of infection was then determined. The viral vectors were designated as pSIREN-shACVR1B-1, pSIREN-shACVR1B-2, pSIRENshScr-1, and pSIREN-shScr-2. The stable transfectants expressing shRNA ACVR1B-1, shRNA ACVR1B-2, shRNA scramble-1 or shRNA scramble-2 in the Sui66 and Sui73 cell lines were designated as Sui66/shACVR1B (Sui66/ shACVR1B-1 and Sui66/shACVR1B-2), Sui66/shScr (Sui66/ shScr-1 and Sui66/shScr-2), Sui73/shACVR1B (Sui73/ shACVR1B-1 and Sui73/shACVR1B-2), and Sui73/shScr (Sui73/shScr-1 and Sui73/shScr-2), respectively.

A full-length cDNA fragment encoding the human $p 21$ gene was introduced into a pQCLIN retroviral vector (Clontech) together with enhanced green fluorescent protein (EGFP) following the internal ribosome entry site sequence (IRES) to monitor the expression of the inserts indirectly. The methods used for viral production and the stable transfectant were described above. The vectors and stable viral transfectant Sui68 cell line was designated as pQCLIN-EGFP, pQLCIN-p21, Sui68/EGFP and Sui68/ p21, respectively.

\section{Antibody}

A goat antibody specific for ACVR1B was obtained from R\&D Systems. Rabbit antibodies specific for SMAD2, phospho-SMAD2, SMAD4, AKT, phospho-AKT, ERK1/ 
2, phospho-ERK1/2, p21, and $\beta$-actin were obtained from Cell Signaling (Beverly, MA).

\section{Western blot analysis}

A western blot analysis was performed as described previously [28]. Briefly, subconfluent cells were washed with cold phosphate-buffered saline (PBS) and harvested with Lysis A buffer containing 1\% Triton X-100, $20 \mathrm{mM}$ Tris- $\mathrm{HCl}$ (pH7.0), $5 \mathrm{mM}$ EDTA, $50 \mathrm{mM}$ sodium chloride, $10 \mathrm{mM}$ sodium pyrophosphate, $50 \mathrm{mM}$ sodium fluoride, $1 \mathrm{mM}$ sodium orthovanadate, and a protease inhibitor mix, Complete ${ }^{\mathrm{Tu}}$ (Roche Diagnostics). Whole-cell lysates were separated using a 5\%-20\% SDS-PAGE and were blotted onto a polyvinylidene fluoride membrane. After blocking with $3 \%$ bovine serum albumin in a TBS buffer (pH8.0) with $0.1 \%$ Tween-20, the membrane was probed with primary antibody. After rinsing twice with TBS buffer, the membrane was incubated with horseradish peroxidase-conjugated secondary antibody and washed, followed by visualization using an ECL detection system (GE Healthcare, Buckinghamshire, United Kingdom) and LAS-3000 (Fujifilm, Tokyo, Japan). When the influence of the ligands was evaluated, the cultured medium was replaced with 1\% FBS medium 6 hours before exposure to the ligands.

\section{Cellular growth assay}

The Sui66-, Sui68-, and Sui73-transfectant cell lines were incubated on 96-well plates at a density of 2,000/well with $200 \mu \mathrm{L}$ of cultured medium at $37^{\circ} \mathrm{C}$ in $5 \% \mathrm{CO}_{2}$. After 24, 48, or 72 hours of incubation, $20 \mu \mathrm{L}$ of MTT [3-(4, 5-dimethyl-thiazoyl-2-yl)2,5-diphenyltetrazolium bromide] solution (Sigma-Aldrich) was added and the culture medium was discarded; the wells were then filled with DMSO. The absorbance of the cultures at $570 \mathrm{~nm}$ was measured using VERSAmax (Japan Molecular Devices, Tokyo, Japan). To evaluate growth in the presence of ligands, we also used an MTT assay. The cell lines (2,000/ well) were transferred to 96-well plates and cultured using $1 \% \mathrm{FBS}$ medium for 24 hours at $37^{\circ} \mathrm{C}$. Then, the ligands (TGFB1: $0,0.1,1$, and $10 \mathrm{ng} / \mathrm{mL}$; activin A: 0,1 , 10 , and $100 \mathrm{ng} / \mathrm{mL}$ ) were added and the incubation was further continued for 72 hours at $37^{\circ} \mathrm{C}$ using $1 \%$ FBS medium. The average O.D. values of the 6 wells were used for a single experiment, and the experiment was performed in triplicate.

\section{Colony formation assay}

Sui66- and Sui73-transfectant cell lines were seeded into 6-well plates at a density of 200 cells/well, and Sui68transfectant cell lines were seeded into 6-well plates at a density of 500 cells/well. After 2 weeks, the cells were washed with PBS and fixed with $4 \%$ paraformaldehyde for $10 \mathrm{~min}$ and then stained with $0.1 \%$ crystal violet for
$15 \mathrm{~min}$; the colonies were then counted under a light microscope. The experiment was performed in triplicate.

\section{Cell cycle distribution analysis}

The cell cycle analyses were performed as described previously [37]. Briefly, cell lines were seeded into 6-cm dishes of $2 \times 10^{5}$ cells and cultured using 1\% FBS medium for 24 hours at $37^{\circ} \mathrm{C}$. Then, the ligands (TGFB1, $1 \mathrm{ng} / \mathrm{mL}$; activin $\mathrm{A}, 10 \mathrm{ng} / \mathrm{mL}$ ) were added, and the incubation was further continued for 48 hours at $37^{\circ} \mathrm{C}$ using $1 \%$ FBS medium. Cells were harvested by trypsinization, washed twice with PBS, and fixed with cold $70 \%$ ethanol at $4^{\circ} \mathrm{C}$ for $30 \mathrm{~min}$. Then, the cells were washed twice with PBS and stained using propidium iodide/RNase Staining Buffer (BD Biosciences, San Jose, CA) at room temperature for $15 \mathrm{~min}$. The cells were analyzed using a flow cytometer (BD FACSCalibur ${ }^{\mathrm{Tn}}$, BD Biosciences), and the cell cycle analysis was performed using ModFit LT software. The experiment was performed in triplicate.

\section{Xenograft studies}

Nude mice (BALB/c nu/nu; 6-week-old females; CLEA Japan, Tokyo, Japan) were used for the in vivo studies and were cared for in accordance with the recommendations for the Handling of Laboratory Animals for Biomedical Research compiled by the Committee on Safety and Ethical Handling Regulations for Laboratory Animals Experiments, Kinki University. The ethical procedures followed and met the requirements of the United Kingdom Coordinating Committee on Cancer Research guidelines. To evaluate tumorigenicity, a suspension of $5 \times 10^{6}$ Sui66- and Sui68-transfectant cells (in $50 \mu \mathrm{L}$ PBS) were subcutaneously inoculated into both flanks of nude mice $(n=7)$. To evaluate the tumor growth, a suspension of $5 \times 10^{6}$ Sui68- and Sui73-transfectant cells (in $50 \mu \mathrm{L}$ PBS) with $50 \mu \mathrm{L}$ of Matrigel were subcutaneously inoculated into the right flanks of nude mice $(n=5)$. The tumor volume was calculated as the length $\times$ width $^{2} \times 0.5$. The tumor formation and volume were assessed every 2 to 3 days. At the end of the experiment, the mice were sacrificed and the xenografts were resected, fixed in 10\% buffered formalin for 6 to 10 hours, and processed for histologic analysis. The method was described previously [38].

\section{Patients and samples}

A total of 29 patients who had been diagnosed as having unresectable PC based on the results of an endoscopic biopsy performed at Kinki University Hospital between April 2007 and March 2008 were enrolled. This study was retrospectively performed and was approved by the institutional review board of the Kinki University Faculty of Medicine. The staging of the PC was determined according to the TNM classification. Among those who 
had a good performance status and received chemotherapy, the PFS was defined as the time from the initiation of chemotherapy until the first observation of disease progression or death from any cause, OS was defined as the time from the initiation of chemotherapy until death from any cause. The response to chemotherapy was evaluated at one month after the start of therapy and every 2 months thereafter using computed tomography according to the Response Evaluation Criteria in Solid Tumors.

\section{DNA extraction}

The endoscopic biopsy samples were immediately stored at $-80^{\circ} \mathrm{C}$. Other biopsy samples obtained from the same location were reviewed by a pathologist to confirm the presence of tumor cells. The DNA was extracted using a QIAamp DNA Micro kit (Qiagen, Hilden, Germany) as described previously [36]. The DNA concentration was determined using the NanoDrop2000 (Thermo Fisher Scientific, Waltham, MA).

\section{Statistical analysis}

Continuous variables were analyzed using the Student $t$-test, and the results were expressed as the average and standard deviations (SD). Dichotomous variables were analyzed using the Fisher exact test. PFS and OS were analyzed using the Kaplan-Meier method and were compared among groups using the log-rank test. The statistical analyses were two-tailed and were performed using Microsoft Excel (Microsoft, Redmond, WA). A P-value of less than 0.05 was considered statistically significant.

\section{Additional file}

Additional file 1: Effects of ligands on the Sui70 cell line (wild-type ACVR1B gene and homozygous deletion of SMAD4 gene). A. Influence of TGFB1 and activin A on cellular growth in the Sui70 cell line. Both TGFB1 $(0.1 \mathrm{ng} / \mathrm{mL}, P=0.42 ; 1 \mathrm{ng} / \mathrm{mL}, P=0.65 ; 10 \mathrm{ng} / \mathrm{mL}, P=0.30)$ and activin A $(1 \mathrm{ng} / \mathrm{mL}, P=0.38 ; 10 \mathrm{ng} / \mathrm{mL}, P=0.47 ; 100 \mathrm{ng} / \mathrm{mL}, P=0.35)$ did not influence the cellular growth. hDEL, homozygous deletion; WT, wild-type. B. Western blot analyses for non-SMAD pathway and p21. Both AKT and ERK $1 / 2$ had already been phosphorylated, and the phosphorylation was not enhanced by activin A. The expression of p21 was not changed by activin $\mathrm{A}$.

\section{Abbreviations \\ ACVR: Activin A receptor; CGH: Comparative genomic hybridization; OS: Overall survival; PBS: Phosphate-buffered saline; PC: Pancreatic cancer: PFS: Progression-free survival; RT-PCR: Reverse-transcription PCR; Scr: Scramble; SD: Standard deviations; sh: Short hairpin; TGFB: Transforming growth factor beta; TGFBR: Transforming growth factor beta receptor.}

\section{Competing interests}

The authors declare that they have no competing interests.

\section{Authors' contributions}

YT designed and participated in the experiments and drafted the manuscript. HS and MK collected clinical samples. HH and MT carried out the experiments with cells. VM and YF carried out the in vivo experiments. YK and KS carried out the clinical sample analyses. Al reviewed the histology. ST performed the statistical analysis. MK and KN conceived the study, participated in its design and coordination, and helped to draft the manuscript. All the authors have read and approved the final manuscript.

\section{Acknowledgment}

We thank Mr. Shinji Kurashimo, Mr. Yoshihiro Mine, Ms. Eiko Honda, Ms. Tomoko Kitayama, and Ms. Ayaka Kurumatani for their technical assistance. This work was supported in part by the Third-Term Comprehensive 10-Year Strategy for Cancer Control and Grant-in Aid for Japan Society for Promotion of Science Fellows.

\section{Author details}

'Department of Genome Biology, Kinki University Faculty of Medicine, 377-2 Ohno-higashi, Osaka-Sayama, Osaka 589-8511, Japan. ${ }^{2}$ Department of Gastroenterology and Hepatology, Kinki University Faculty of Medicine, Osaka-Sayama, Osaka, Japan. ${ }^{3}$ Department of Pathology, Kinki University Faculty of Medicine, Osaka-Sayama, Osaka, Japan.

Received: 13 November 2013 Accepted: 20 May 2014

Published: 27 May 2014

\section{References}

1. Moore MJ, Goldstein D, Hamm J, Figer A, Hecht JR, Gallinger S, Au HJ, Murawa P, Walde D, Wolff RA, Campos D, Lim R, Ding K, Clark G, Voskoglou-Nomikos T, Ptasynski M, Parulekar W, National Cancer Institute of Canada Clinical Trials Group: Erlotinib plus gemcitabine compared with gemcitabine alone in patients with advanced pancreatic cancer: a phase III trial of the National Cancer Institute of Canada Clinical Trials Group. J Clin Oncol 2007, 25:1960-1966.

2. Conroy T, Desseigne F, Ychou M, Bouché O, Guimbaud R, Bécouarn $Y$, Adenis A, Raoul JL, Gourgou-Bourgade S, de la Fouchardière C, Bennouna J, Bachet JB, Khemissa-Akouz F, Péré-Vergé D, Delbaldo C, Assenat E, Chauffert B, Michel P, Montoto-Grillot C, Ducreux M, Groupe Tumeurs Digestives of Unicancer; PRODIGE Intergroup: FOLFIRINOX versus gemcitabine for metastatic pancreatic cancer. N Engl J Med 2011, 364:1817-1825.

3. Von Hoff DD, Ervin T, Arena FP, Chiorean EG, Infante J, Moore M, Seay T, Tjulandin SA, Ma WW, Saleh MN, Harris M, Reni M, Dowden S, Laheru D, Bahary N, Ramanathan RK, Tabernero J, Hidalgo M, Goldstein D, Van Cutsem E, Wei X, Iglesias J, Renschler MF: Increased survival in pancreatic cancer with nab-paclitaxel plus gemcitabine. N Eng/ J Med 2013, 369:1691-1703.

4. Siegel R, Naishadham D, Jemal A: Cancer statistics, 2013. CA Cancer J Clin 2013, 63:11-30.

5. Bardeesy N, DePinho RA: Pancreatic cancer biology and genetics. Nat Rev Cancer 2002, 2:897-909.

6. Singh P, Srinivasan R, Wig JD: Major molecular markers in pancreatic ductal adenocarcinoma and their roles in screening, diagnosis, prognosis, and treatment. Pancreas 2011, 40:644-652.

7. Macgregor-Das AM, lacobuzio-Donahue CA: Molecular pathways in pancreatic carcinogenesis. J Surg Oncol 2013, 107:8-14.

8. Baker CH, Solorzano CC, Fidler IJ: Blockade of vascular endothelial growth factor receptor and epidermal growth factor receptor signaling for therapy of metastatic human pancreatic cancer. Cancer Res 2002, 62:1996-2003.

9. Day JD, Digiuseppe JA, Yeo C, Lai-Goldman M, Anderson SM, Goodman SN, Kern SE, Hruban RH: Immunohistochemical evaluation of HER-2/neu expression in pancreatic adenocarcinoma and pancreatic intraepithelial neoplasms. Hum Pathol 1996, 27:119-124.

10. Safran $H$, lannitti $D$, Ramanathan R, Schwartz JD, Steinhoff M, Nauman C, Hesketh P, Rathore R, Wolff R, Tantravahi U, Hughes TM, Maia C, Pasquariello T, Goldstein L, King T, Tsai JY, Kennedy T: Herceptin and gemcitabine for metastatic pancreatic cancers that overexpress HER-2/neu. Cancer Invest 2004, 22:706-712.

11. Harder J, Ihorst $G$, Heinemann $V$, Hofheinz $R$, Moehler M, Buechler $P$, Kloeppel G, Röcken C, Bitzer M, Boeck S, Endlicher E, Reinacher-Schick A, Schmoor C, Geissler M: Multicentre phase II trial of trastuzumab and capecitabine in patients with HER2 overexpressing metastatic pancreatic cancer. Br J Cancer 2012, 106:1033-1038.

12. Ikushima $\mathrm{H}$, Miyazono K: TGFbeta signalling: a complex web in cancer progression. Nat Rev Cancer 2010, 10:415-424.

13. Akhurst RJ, Hata A: Targeting the TGF $\beta$ signalling pathway in disease. Nat Rev Drug Discov 2012, 11:790-811. 
14. Hilbig A, Oettle $H$ : Transforming growth factor beta in pancreatic cancer. Curr Pharm Biotechnol 2011, 12:2158-2164

15. Birnbaum DJ, Mamessier E, Birnbaum D: The emerging role of the TGF $\beta$ tumor suppressor pathway in pancreatic cancer. Cell Cycle 2012, 11:683-686

16. Ijichi H, Chytil A, Gorska AE, Aakre ME, Fujitani Y, Fujitani S, Wright CV, Moses HL: Aggressive pancreatic ductal adenocarcinoma in mice caused by pancreas-specific blockade of transforming growth factor-beta signaling in cooperation with active Kras expression. Genes Dev 2006, 20:3147-3160.

17. Izeradjene K, Combs C, Best M, Gopinathan A, Wagner A, Grady WM, Deng CX, Hruban RH, Adsay NV, Tuveson DA, Hingorani SR: Kras(G12D) and Smad4/ Dpc4 haploinsufficiency cooperate to induce mucinous cystic neoplasms and invasive adenocarcinoma of the pancreas. Cancer Cell 2007, 11:229-243.

18. Kleeff J, Ishiwata T, Friess H, Büchler MW, Korc M: Concomitant overexpression of activin/inhibin beta subunits and their receptors in human pancreatic cancer. Int J Cancer 1998, 77:860-868.

19. Su GH, Bansal R, Murphy KM, Montgomery E, Yeo CJ, Hruban RH, Kern SE: ACVR1B (ALK4, activin receptor type 1B) gene mutations in pancreatic carcinoma. Proc Natl Acad Sci U S A 2001, 98:3254-3257.

20. Lonardo E, Hermann PC, Mueller MT, Huber S, Balic A, Miranda-Lorenzo I, Zagorac S, Alcala S, Rodriguez-Arabaolaza I, Ramirez JC, Torres-Ruíz R, Garcia E, Hidalgo M, Cebrián DÁ, Heuchel R, Lour M, Berger F, Bartenstein P, Aicher A, Heeschen C: Nodal/Activin signaling drives self-renewal and tumorigenicity of pancreatic cancer stem cells and provides a target for combined drug therapy. Cell Stem Cell 2011, 9:433-446.

21. Hempen PM, Zhang L, Bansal RK, lacobuzio-Donahue CA, Murphy KM, Maitra A, Vogelstein B, Whitehead RH, Markowitz SD, Willson JK, Yeo CJ, Hruban RH, Kern SE: Evidence of selection for clones having genetic inactivation of the activin A type II receptor (ACVR2) gene in gastrointestinal cancers. Cancer Res 2003, 63:994-999.

22. Bauer J, Sporn JC, Cabral J, Gomez J, Jung B: Effects of activin and TGF $\beta$ on p21 in colon cancer. PLoS One 2012, 7:e39381.

23. McPherson SJ, Mellor SL, Wang H, Evans LW, Groome NP, Risbridger GP: Expression of activin A and follistatin core proteins by human prostate tumor cell lines. Endocrinology 1999, 140:5303-5309.

24. Yokomuro S, Tsuji H, Lunz JG 3rd, Sakamoto T, Ezure T, Murase N, Demetris AJ: Growth control of human biliary epithelial cells by interleukin 6 , hepatocyte growth factor, transforming growth factor beta1, and activin A: comparison of a cholangiocarcinoma cell line with primary cultures of non-neoplastic biliary epithelial cells. Hepatology 2000, 32:26-35.

25. Panopoulou E, Murphy C, Rasmussen H, Bagli E, Rofstad EK, Fotsis T: Activin A suppresses neuroblastoma xenograft tumor growth via antimitotic and antiangiogenic mechanisms. Cancer Res 2005, 65:1877-1886.

26. Burdette JE, Jeruss JS, Kurley SJ, Lee EJ, Woodruff TK: Activin A mediates growth inhibition and cell cycle arrest through Smads in human breast cancer cells. Cancer Res 2005, 65:7968-7975.

27. Ramachandran A, Marshall ES, Love DR, Baguley BC, Shelling AN: Activin is a potent growth suppressor of epithelial ovarian cancer cells. Cancer Lett 2009, 285:157-165

28. Kaneda H, Arao T, Matsumoto K, De Velasco MA, Tamura D, Aomatsu K, Kudo K, Sakai K, Nagai T, Fujita Y, Tanaka K, Yanagihara K, Yamada Y, Okamoto I, Nakagawa K, Nishio K: Activin A inhibits vascular endothelial cell growth and suppresses tumour angiogenesis in gastric cancer. $\mathrm{Br} J$ Cancer 2011, 105:1210-1217.

29. Weiss RH: p21Waf1/Cip1 as a therapeutic target in breast and other cancers. Cancer Cell 2003, 4:425-429.

30. Mu Y, Gudey SK, Landström M: Non-Smad signaling pathways. Cell Tissue Res 2012, 347:11-20.

31. Yanagihara K, Takigahira M, Tanaka H, Arao T, Aoyagi Y, Oda T, Ochiai A, Nishio K: Establishment and molecular profiling of a novel human pancreatic cancer panel for 5-FU. Cancer Sci 2008, 99:1859-1864.

32. Goggins M, Shekher M, Turnacioglu K, Yeo CJ, Hruban RH, Kern SE: Genetic alterations of the transforming growth factor beta receptor genes in pancreatic and biliary adenocarcinomas. Cancer Res 1998, 58:5329-5332.

33. Grady WM, Myeroff LL, Swinler SE, Rajput A, Thiagalingam S, Lutterbaugh JD, Neumann A, Brattain MG, Chang J, Kim SJ, Kinzler KW, Vogelstein B, Willson JK, Markowitz S: Mutational inactivation of transforming growth factor beta receptor type II in microsatellite stable colon cancers. Cancer Res 1999, 59:320-324.
34. Gu Z, Nomura M, Simpson BB, Lei H, Feijen A, van den Eijnden-van RJ, Donahoe PK, Li E: The type I activin receptor ActRIB is required for egg cylinder organization and gastrulation in the mouse. Genes Dev 1998, 12:844-857.

35. Furuta K, Arao T, Sakai K, Kimura H, Nagai T, Tamura D, Aomatsu K, Kudo K, Kaneda H, Fujita Y, Matsumoto K, Yamada Y, Yanagihara K, Sekijima M, Nishio K: Integrated analysis of whole genome exon array and array-comparative genomic hybridization in gastric and colorectal cancer cells. Cancer Sci 2012, 103:221-227.

36. Matsumoto K, Arao T, Hamaguchi T, Shimada Y, Kato K, Oda I, Taniguchi H, Koizumi F, Yanagihara K, Sasaki H, Nishio K, Yamada Y: FGFR2 gene amplification and clinicopathological features in gastric cancer. $\mathrm{Br} J$ Cancer 2012, 106:727-732.

37. Tamura D, Arao T, Tanaka K, Kaneda H, Matsumoto K, Kudo K, Aomatsu K, Fujita Y, Watanabe T, Saijo N, Kotani Y, Nishimura Y, Nishio K: Bortezomib potentially inhibits cellular growth of vascular endothelial cells through suppression of G2/M transition. Cancer Sci 2010, 101:1403-1408.

38. Kaneda H, Arao T, Tanaka K, Tamura D, Aomatsu K, Kudo K, Sakai K, De Velasco MA, Matsumoto K, Fujita Y, Yamada Y, Tsurutani J, Okamoto I, Nakagawa K, Nishio K: FOXQ1 is overexpressed in colorectal cancer and enhances tumorigenicity and tumor growth. Cancer Res 2010, 70:2053-2063.

doi:10.1186/1476-4598-13-126

Cite this article as: Togashi et al:: Homozygous deletion of the activin A receptor, type IB gene is associated with an aggressive cancer phenotype in pancreatic cancer. Molecular Cancer 2014 13:126.

\section{Submit your next manuscript to BioMed Central and take full advantage of:}

- Convenient online submission

- Thorough peer review

- No space constraints or color figure charges

- Immediate publication on acceptance

- Inclusion in PubMed, CAS, Scopus and Google Scholar

- Research which is freely available for redistribution 